\title{
Harold Garfinkel, 29 October 1917-21 April 2011
}

\author{
Giolo Fele
}

Published online: 3 May 2012

(C) Springer Science+Business Media B.V. 2012

With the death of Harold Garfinkel another of the masters of the last century has left us. Garfinkel was the founding father of ethnomethodology, and nobody today concerned with the meaning of social action can gainsay the deeply innovative, indeed revolutionary, work carried forward by Garfinkel for at least 60 years.

Garfinkel remains an extremely influential yet controversial figure in the social sciences. And not only in theoretical terms. Some of his recommendations for research, such as the unique adequacy requirement, have puzzled generations of researchers. Garfinkel maintained that the researcher must become an expert member of the 'tribe' that s/he sets out to study; s/he must be an integral part of the specific professional culture of interest; s/he must blend into the constitutive practices of the social group. On the one hand, this requirement discouraged the least motivated researchers, or perhaps those who realized that access to an academic career depended on their remaining firmly within a recognized disciplinary area. On the other hand, those few who decided instead to follow Garfinkel's rigorous and demanding route were left to themselves in a sort of intellectual limbo, not fully recognized by their field of preference and no longer accepted by their field of provenance. They were indeed 'bastards' (the term which ethnomethodologists often use to describe themselves).

On the other hand, the unique adequacy requirement was the gold standard for membership of the group of ethnomethodologists. It was the measure used to establish who was an insider and who an outsider, who had 'understood' ethnomethodology and who instead simply parroted complicated notions and abstruse concepts. But this 'hard core' group has never found a centre of academic or disciplinary gravity. For three reasons. Firstly, Garfinkel's writings are subject to 'interpretation': they are the reference texts, but at the same time their resistance to

G. Fele $(\bowtie)$

Dipartimento di Sociologia e Ricerca Sociale, University of Trento,

Via Verdi, 26, 38122 Trento, Italy

e-mail: giolo.fele@unitn.it 
hasty or schematic reading make them ideal material for discussion, specification, clarification and illustration, without creating a stable or cumulable corpus of doctrines, definitions and concepts (on reading Garfinkel, the Nietzsche of Ecce Homo comes to mind: "Whoever knows how to breathe the air of my writings knows that it is an air of heights, a strong air. One must be made for it, otherwise there is no small danger of being chilled by it". Prologue 3). Secondly, the set of researchers who constitutes the living 'warp and woof' of ethnometodological work appears diversified, scattered and particularly quarrelsome. More than a network, a community, or a team, they can be described as a set of 'currents,' or better unique personalities who reject association with each other. Thirdly, the university departments and faculties that host or hire thnomethodologists can be counted on the fingers of one hand: and young researchers are often hired because they know how to do something else. In short, ethnomethodology has not been able to consolidate itself in academe because of a confused university policy of disciplinary reproduction.

Garfinkel's death prompts reflection with a certain detachment on the story so far. But at the same time it invites direct examination of his work. Garfinkel's written output published to date is hardly a deluge. But a series of publishing initiatives have been announced which promise to furnish researchers with enormous quantities of materials and texts which Garfinkel did not want to publish in his lifetime for various reasons. Only some of them have already been brought out, thanks to the work of Anne Rawls (Garfinkel 2002, 2006/1948, 2008/1952).

The question that I believe arises once again is the usual one: What is ethnomethodology? We have all learned to give a textbook answer to the question and now, after some years, we know more or less what ethnomethodology is. But with Garfinkel's death, the question no longer concerns banal issues of scholastic definition; rather, it concerns ethnomethodology's disciplinary future. How should ethnomethodology be considered? As a 'discipline,' an approach, a movement, a school, a science?

On re-reading Garfinkel's work, one gains the impression that he was indeed "onto something big," as he put it to an audience of supporters: "Tonight I've taken as my fatherly job, having been invited to address a familial mix, to remind the company of us that we're onto something very big" (Garfinkel 2007: 13). We can perhaps say that Garfinkel was engaged in formulating a new view of social phenomena, one difficult to frame 'within' sociology. The more I think about it, the more I believe that Garfinkel was not simply inventing a recognizable approach (however eccentric and heterodox) like symbolic interactionism (to which ethnomethodology has often been likened). Not even Garfinkel would have been satisfied with considering ethnomethodology an adjectival variant of sociology (ethnometodological), just as there exists a pragmatist or phenomenological, or some other, sociology. Although ethnomethodology was born and developed within the disciplinary confines of sociology, it seems to have forcefully asserted its autonomy from the latter. It is perhaps this that explains the misunderstanding of which ethnomethodologists (except for Garfinkel) have constantly complained in regard to interpretations by certain contemporary social theorists, polemics and attacks. Garfinkel always spoke of "ethnomethodological alternates" with respect to 
formal social science; but one perhaps understands his position better on considering that it was not his intention to refound sociology or to compete with it (something that mainstream sociologists have always accused ethnomethodology of doing). Instead, perhaps, did Garfinkel want simply to point out a disciplinary alternative? Was he founding a new discipline alongside sociology, as well as psychology, anthropology, etc.? (Those interested might usefully compare the case of Freud and the birth of psychoanalysis 'in opposition to' psychiatry and medicine). Of course, matters are more complicated than can be described in these few lines. But suffice it to consider the subject matter of ethnomethodology: which can be summed up as the study of how groups self-regulate themselves (another definition!). Erving Goffman, in a very similar but certainly more recognizable manner, spoke of the "interaction order". This is a highly distinctive view of social phenomena which has nothing to do with individuals and social structures. One may therefore say that sociology and ethnomethodology have never understood each other because their objects of inquiry were different!

In this way Garfinkel's ethnomethodology is able to bring together apparently different contexts and phenomena (pertaining to social life like traffic jams and conversation) but also less recognizable ones (such as the logic of information systems or the collective behaviour of animals or the dynamic of the stock exchange). This also explains theoretical references that may seem rather heterodox if viewed from a classical sociological standpoint (Durkheim and Parsonsironically, Garfinkel's ethnomethodology has traditionally been regarded as the polar opposite of the sociology represented by Durkheim and Parsons-but also by authors like Husserl, Heidegger, Merleau-Ponty, Gurwitsch, or Wittgenstein, who do not appear on the compulsory reading lists of sociology students).

Whether this is the authentic project of ethnomethodology is a matter of debate. Whether the project is (or will be) a success is entirely to be established (interesting in this regard is a recent multimillion-dollar call for research proposals sponsored by the US Defense Department, which explicitly uses ethnomethodology as its theoretical referent, while equally explicitly stating that the Department is not interested in sociological or anthropological approaches). The work that will be done from now on will serve to clarify both questions.

\section{References}

Garfinkel, H. (2002). Ethnomethodology's program: Working out Durkheim's aphorism. Lanham, MD: Rowman and Littlefield.

Garfinkel, H. (2006/1948). Seeing sociologically. Boulder, CO: Paradigm Publishers.

Garfinkel, H. (2007). Lebenswelt origins of the sciences: Working out Durkheim's aphorism. Human Studies, 30, 9-56.

Garfinkel, H. (2008/1952). Toward a sociological theory of information. Boulder, CO: Paradigm Publishers. 